\title{
Psychiatric co-morbidity and attachment styles in obese adults: A comparative study with healthy volunteers
}

\author{
Yetişkin obez bireylerde psikiyatrik ek tanı ve bağlanma stilleri:Sağlıkı \\ gönüllülerle karşılaştırmalı bir çalışma
}

\author{
Demet Gulec Oyekcin¹, Erkan Melih Sahin², Ebru Aldemir ${ }^{3}$ \\ ${ }^{1}$ Assoc. Prof., Onsekiz Mart University, Faculty of Medicine, Department of Psychiatry, Canakkale, Turkey \\ 2Prof., Onsekiz Mart University, Faculty of Medicine, Department of Family Practice, Canakkale, Turkey \\ ${ }^{3}$ M.D., Ege University, Institute on Drug Abuse, Toxicology and Pharmaceutical Science, İzmir, Turkey
}

\section{SUMMARY}

Objective: Psychiatric co-morbidity and attachment issues are prevalent in obese patients. A possible relationship between insecure attachment styles and eating disorder risk has been proposed. The aim of this study is to determine the psychiatric co-morbidity, attachment styles and related risk factors in obese patients. Method: Obese patients with body mass index of $30 \mathrm{~kg} / \mathrm{m} 2$ or higher and non-obese controls matched for age, sex and education were included with a total sample of 173 participants. Diagnostic assessment using Structured Clinical Interview for DSM-IV Axis I Disorders and the Adult Attachment Scale, Hamilton Depression and Hamilton Anxiety scales were carried out. Attachment styles were classified as-anxious/ambivalent, avoidant and secure. The anxious/ambivalant and avoidant groups were combined and compared with the secure group. Results: Fifty three $(40.8 \%)$ obese patients had psychiatric disorders including major depression $(n=44$; $33.8 \%$ ). Anxiety was found to be a risk factor with obesity and $\mathrm{BMI}$ in both patients with or without any psychiatric co-morbidity. Psychiatric co-morbidity was significantly higher in obese patients $(40.8 \%)$ than controls (18.6\%). $55.4 \%$ of the participants had insecure attachment styles, it was significantly higher in obese patients. Insecure attachment styles were higher with psychiatric co-morbidity. Discussion: Psychiatric co-morbidity and insecure attachment styles were prevalent in obese patients, and the symptom of anxiety was found to be a predictor of obesity and body mass index. Psychiatric examinations including attachment styles and anxiety will help to advance better treatment strategies for obese patients.

Key Words: Anxiety, depression, eating behavior, obesity

(Turkish J Clinical Psychiatry 2018;21:326-333)

DOI: $10.5505 / k p d .2018 .88700$
ÖZET

Amaç: Obez hastalarda psikiyatrik ek tanı ve bağlanma sorunları yaygındır. Güvensiz bağlanma stilleri ile yeme bozukluğu arasında bağlantı olduğu ileri sürülmektedir. Bu çalışmanın amacı, obez bireylerdeki psikiyatrik ek tanı, bağlanma stilleri ve ilişkili risk faktörlerini belirlemektir. Yöntem:Beden kitle indeksi $30 \mathrm{~kg} / \mathrm{m} 2$ ve üstü olan obez bireyler ile; yaş, cinsiyet ve eğitim açısından eşleştirilmiş obez olmayan kontrollerden oluşan 173 olgu çalışmaya alındı. Bu olgulara, DSM-IV Eksen I Bozuklukları için Yapılandııılmış Klinik Görüşme, Erişkin Bağlanma Biçimi Ölçeği, Hamilton Depresyon ve Hamilton Anksiyete Derecelendirme Ölçekleri uygulandı. Bağlanma stilleri; anksiyöz/ambivalan, kaçıngan ve güvenli olaraksınıflandırıldı. Anksiyöz/ambivalan ve kaçıngan gruplar birleştirilerek güvenli bağlanma grubu ile karşılaştırıldı. Bulgular: Obez bireylerin \%40.8'inde $(n=53)$, başta major depresyon $(n=44, \% 33.8)$ olmak üzere psikiyatrik ek tanı mevcuttu. Obez hastalarda psikiyatrik ek tanı (\%40.8), sağlıklı kontrollerden (\%18.6) anlamlı olarak daha fazlaydı. Psikiyatrik ektanısı olan veya olmayan bireylerde anksiyete, obezite ve beden kitle indeksi açısından bir risk faktörü olarak bulundu. Olguların \%55.4'ünde güvenli olmayan bağlanma vardı ve bu, obez hastalarda anlamlı olarak daha sıktı. Psikiyatrik ek tanı varlığında güvensiz bağlanma stili daha yaygın görüldü. Sonuç: Obez hastalarda psikiyatrik ek tanı ve güvensiz bağlanma stilleri yaygındı ve anksiyete, obezite ve beden kitle indeksi açısından bir öngörücü faktör olarak saptandı. Obez hastalarda, bağlanma stilleri ve anksiyeteyi de içeren psikiyatrik değerlendirmeler, bu olgular için daha iyi tedavi stratejileri geliştirilmesinde yardımcı olacaktır.

Anahtar Sözcükler: Anksiyete, depresyon, yeme davranışı, obezite 


\section{INTRODUCTION}

Obesity is a complex and multifaceted problem that has been described as a major cause of mortality and morbidity (1). Psychological factors are believed to be crucial in the etiology of obesity. These factors include internal and external forces, social, cultural, developmental and psychopathological processes (2). Psychopathology is more prevalent in obese patients than the general population. Psychopathology mainly consists of depression, anxiety and impaired self-esteem (3). The prevalance of depression is higher in obese population (4).

A broad range of biological, behavioural, cognitive and social factors may underpin the relationship between obesity and depression. Various psychological variables are significantly associated with the relationship between obesity and depressive symptoms (5). However, the psychological risks of obesity are not entirely understood.

Attachment theory is only one of the theories which helps to explain the psychological causes of obesity (6). To understand the relationship between this psychological modality and obesity we have to review the attachment theory in brief.

Attachment style is a concept that derives from John Bowlby's attachment theory and refers to a person's characteristic ways of relating to intimate caregiving and receiving relationships with attachment figures (7). If an individual encounters a caregiver who gives a healthy response to a particular stress during infancy, she/he ultimately learns to seek appropriate ways and supports to cope with her/his stress. This allows her/him to develop secure attachment style. However, if the individual receives insusceptible or irregular responses to stress from caregiver, she/he will develop inappropriate coping strategies against stress, resulting in unsafe attachment. Attachment theory provides both theoretical and practical benefits for professionals who gives psychological support to people with medical and surgical illnesses (8). Relational experiences with attachment figures in childhood are important, and insecure attachment has been longitudinally linked with the development of dis- turbed eating behaviors (9).

Research to date suggests a possible relationship between attachment insecurity and risk for eating disorders (10). Furthermore, attachment anxiety is also found to be related to the severity of eating disorder symptoms and body mass index (BMI) $(11,12)$.

The aim of this study is to investigate the prevalence of psychiatric co-morbidity and attachment styles in obese population and psychological risk factors for obesity.

\section{METHOD}

This was a descriptive, cross-sectional controlled study with a sample of 173 participants. The study was conducted at the Canakkale Onsekiz Mart University's Medical Faculty, Psychiatry Department and Endocrinology Department between November 2011 and December 2012. Those who met the inclusion and exclusion criteria of the study were enrolled. This study was conducted following ethical guidelines with the administrative permission of the Canakkale Onsekiz Mart University Hospital and the consent of the participants.

\section{Participants}

Patients were recruited for this study who have been diagnosed as obese with BMI of $30 \mathrm{~kg} / \mathrm{m}^{2}$ or higher at the endocrinology department. Participants for a non-obese control sample were also recruited from accompanying people and hospital staff and matched by age, sex and education. Being 18 years of age or older and having sufficient education to appropriately fill out self-report scales were criteria for inclusion in the study. Patients with severe medical disorders (ie. cardiac, thyroid, neurological disorders, decompensated diabetes), pre-existing psychotic disorders, physical illness, current substance abuse and mental retardation according to the medical records were excluded. 130 obese patients and 43 controls matched by age and education met the inclusion criterias. 


\section{Assessment and Measures}

Patients that matched the criteria for inclusion were invited to participate in the study. After receiving both verbal and written consent from participants, a diagnostic assessment was carried out by an experienced clinical psychiatrist using the Structured Clinical Interview for DSM-IV [SCID] Axis I Disorders (13) for all participants. Demographic data including age, sex, marital and educational status, living place were collected with a questionnaire. Participants' BMI was calculated based on self-reports of height and weight that were confirmed by the endocrinology department's records.

Hamilton Depression Rating Scale (HAM-D), a 17-item scale was administered to the patients, which was adapted to meet the reliability and validity of the Turkish version (14).

Hamilton Anxiety Rating Scale (HAM-A), a 14item scale was administered to the patients which was adapted to meet the reliability and validity of the Turkish version (15).

Adult Attachment Scale: Attachment is a trait that is difficult to measure, as it is based on the participant's statements. The participants' traits of attachment can be measured by interpretation of the participant's schemes about him/herself. Measurement of attachment has two parts. The first part was developed by Hazan and Shaver (16) and it contains three parts including descriptions of adulthood (secure, anxious/ambivalent and avoidant), childhood traits related to parents, and general behavioral features. The latter part was developed by Mikulincer and colleges (17) and contains 15 parameters, which participants were asked to score from 1 to 7 . Each of the three attachment formats were assessed by 5 parameters, and the format that had the highest score indicated the individual's attachment type. Kesebir and collegues (18) confirmed the validity and reliability of the Turkish version of this scale which was used in the study.

\section{Statistics}

After the collected data were transferred to digital media, frequency distributions were expressed with absolute numbers and percentages; continuous variables were calculated by mean and standard deviation. Body Mass Index (BMI) was calculated with the formula as follows: weight $(\mathrm{kg}) / \mathrm{height}^{2}$ $\left(\mathrm{m}^{2}\right)$. Patients that had a $\mathrm{BMI} \geq 30$ were considered obese. HAM-A vs HAM-D scale scores were used as continuous variables. As mentioned above, attachment formats were classified into 3 groups, with anxious/ambivalent and avoidant groups being combined and compared to the secure group. Continuous variables were tested for whether they fit to normal distribution before choosing statistical tests.

Based on the SCID interview results, participants were encoded as either with or without concurrent psychiatric disorders.

To determine differences in categorical data, Pearsons' chi-square test was used. Kendall's tau b test was selected for correlation analysis. Logistic regression models were used for obesity and concurrent psychiatric disorder variables, while linear regressions were used for BMI and backward elimination was used after all possible independent variables were included. The significance level was set at $\mathrm{p}<0.05$.

\section{RESULTS}

One hundred seventy three (173) participants were recruited, 130 of them were obese (35 of them were Class I, 49 of them were Class II and 46 of them were Class III obese) and 43 of them were nonobese ( 2 of them were underweight, 24 of them were normal weight and 17 of them were overweight) healthy controls. One hundred thirty-nine (139) of the participants $(80.3 \%)$ were women, 107 $(61.8 \%)$ of them were married and $140(80.9 \%)$ had moderate socioeconomic status. The sociodemographic features of the participants are presented in Table 1 . The mean age for obese patients was $41.9 \pm 13.7$ (18-68) years, and the mean age of the control group was $36.3 \pm 16.0$ (18-68) years. BMI, HAM-A and HAM-D scale scores of the obese 
Table 1. Sociodemographic Features

\begin{tabular}{|c|c|c|c|c|}
\hline & & Obese group & Control group & $\begin{array}{c}\text { Statistical } \\
\text { analysis }\end{array}$ \\
\hline \multirow[t]{2}{*}{ Sex } & Female & $100(81.3 \%)$ & $39(78.0 \%)$ & $x^{2}=0.245$ \\
\hline & Male & $23(17.7 \%)$ & $11(22.0 \%)$ & $p=0.620$ \\
\hline \multirow{2}{*}{\multicolumn{2}{|c|}{ Age (years) }} & $106+128$ & $102+16$ & $\mathrm{U}=3034.5$ \\
\hline & & $40.6 \pm 13.8$ & $40.2 \pm 10.1$ & $\mathrm{p}=0.892$ \\
\hline \multirow{4}{*}{$\begin{array}{r}\text { Marital } \\
\text { status }\end{array}$} & Single & $31(25.2 \%)$ & $18(36.0 \%)$ & $\mathrm{x}^{2}=2.846$ \\
\hline & Married & 78 (63.4\%) & $29(58.0 \%)$ & $\mathrm{p}=0.584$ \\
\hline & Widowed & $9(7.3 \%)$ & $2(4.0 \%)$ & \\
\hline & Divorced & $4(3.3 \%)$ & $1(2.0 \%)$ & \\
\hline \multirow{2}{*}{\multicolumn{2}{|c|}{ Years of education }} & $7.9 \pm 4.4$ & $9.3 \pm 4.8$ & $\mathrm{U}=2561.0$ \\
\hline & & & & $\mathrm{p}=0.071$ \\
\hline \multirow{3}{*}{ SES* } & Poor & $20(16.3 \%)$ & $6(12.0 \%)$ & $\mathrm{x}^{2}=3.154$ \\
\hline & Moderate & $100(81.3 \%)$ & $40(80.0 \%)$ & $\mathrm{p}=0.207$ \\
\hline & High & $3(2.4 \%)$ & $4(8.0 \%)$ & \\
\hline \multirow{3}{*}{$\begin{array}{r}\text { Living } \\
\text { place }\end{array}$} & Village & $12(9.8 \%)$ & $7(14.0 \%)$ & $\mathrm{x}^{2}=3.023$ \\
\hline & Town & $46(37.4 \%)$ & $12(24.0 \%)$ & $\mathrm{p}=0.221$ \\
\hline & City & $65(52.8 \%)$ & $31(62.0 \%)$ & \\
\hline
\end{tabular}

*SES: Socioeconomic status

patients and control group are presented in Table 2 .

\section{Psychopathologic Properties of the Obese and Control Groups}

SCID-I psychiatric disorders of both groups are summarized in Table 3. Fifty three $(40.8 \%)$ obese patients had concurrent psychiatric disorders while 8 (18.6\%) control group participants had concurrent psychiatric disorders.

Concurrent psychiatric disorders were significantly higher in obese groups $(40.8 \%)$ when compared to control groups $(18.6 \%)\left(\mathrm{x}^{2}=6.954 ; \mathrm{p}=0.010\right)$.

\section{Attachment Styles}

Overall, secure, anxious, and avoidant attachment types were observed in 86 (49.7\%), 59 (34.1\%) and $28(16.2 \%)$ participants, respectively.

Table 2. BMI, HAM-A and HAM-D scale scores of the participants according to the study groups

\begin{tabular}{cccc}
\hline & $\begin{array}{c}\text { Obese } \\
(\mathbf{n}=130)\end{array}$ & $\begin{array}{c}\text { Control } \\
(\mathbf{n}=43)\end{array}$ & $\begin{array}{c}\text { Statistical } \\
\text { analysis }\end{array}$ \\
\hline BMI $\left(\mathbf{k g} / \mathbf{m}^{2}\right)^{*}$ & $39.3 \pm 6.6$ & $24.0 \pm 3.8$ & $\mathrm{U}=226.0$ \\
& $(30.1-61.7)$ & $(17.3-29.9)$ & $\mathrm{p}<0.001$ \\
\hline HAM-A** & $20.8 \pm 11.7$ & $12.7 \pm 10.4$ & $\mathrm{U}=1867.0$ \\
& $(0-47)$ & $(0-49)$ & $\mathrm{p}<0.001$ \\
\hline HAM-D*** & $9.9 \pm 6.6$ & $6.6 \pm 4.6$ & $\mathrm{U}=2289.0$ \\
& $(0-29)$ & $(0-18)$ & $\mathrm{p}=0.008$ \\
\hline
\end{tabular}

*BMI: Body mass index **HAM -A: Hamilton Anxiety Rating

Scale score ***HAM -D: Hamilton Depression Rating Scale score
Fifty eight (44.6\%) obese patients indicated secure attachment, $46(35.4 \%)$ anxious attachment and 26 $(20.0 \%)$ avoidant attachment. Twenty eight $(65.1 \%)$ patients with normal weight indicated secure attachment, $13(30.2 \%)$ anxious attachment and $2(4.7 \%)$ avoidant attachment. When anxious/ambivalant and avoidant type groups were combined, patients with normal weight were more likely to have a secure attachment type than obese patients $(65.1 \%$ to $44.6 \%)\left(x^{2}=5.432 ; p=0.023\right)$.

When anxious/ambivalant and avoidant groups were combined, insecure attachment was more common in women than men $(56.1 \%$ to $26.5 \%)$ $\left(x^{2}=9.603 ; p=0.002\right)$.

Patients with concurrent psychiatric disorders had a tendency to have insecure attachment (tau$\mathrm{b}=0.275, \mathrm{p}<0.001)$.

\section{Regression Analysis of Risk Factors Related to Obesity}

Risk factors related to obesity were analyzed with the logistic regression model. The "backward" elimination method was performed with an accuracy rate of $75.1 \%$. Independent variables including age, gender, years of education, level of income, Hamilton depression score, concurrent psychiatric disorder and attachment type were found to be ineffective so they were exluded from model. Only 
Psychiatric co-morbidity and attachment styles in obese adults: A comparative study with healthy volunteers

Table 3. SCID-I Psychiatric Disorders

\begin{tabular}{|c|c|c|}
\hline Psychiatric Diagnosis & $\begin{array}{l}\text { Obese } \\
\mathrm{n}(\%)\end{array}$ & $\begin{array}{c}\text { Control } \\
\mathrm{n}(\%)\end{array}$ \\
\hline Major depression & $44(33.8 \%)$ & $5(11.6 \%)$ \\
\hline Generalized anxiety disorder & $5(3.8 \%)$ & - \\
\hline Panic disorder & $2(1.5 \%)$ & - \\
\hline Bipolar disorder & $1(0.8 \%)$ & $2(4.6 \%)$ \\
\hline Conversion disorder & $1(0.8 \%)$ & - \\
\hline Somatization disorder & - & $1(2.3 \%)$ \\
\hline$(p=0.010)$ & $53(40.8 \%)$ & $8(18.6 \%)$ \\
\hline
\end{tabular}

the Hamilton anxiety score was included (Table 4).

\section{Linear Regression Analysis of Factors Related to BMI}

Factors related to BMI were analyzed with the linear regression model. After using the "backward" elimination method, gender, living environment, years of education, Hamilton depression score, psychiatric co-morbidity and attachment type were found to be ineffective independent variables and therefore were excluded from model. Age, level of income and Hamilton anxiety score were included (Table 5). The model was statistically significant $(\mathrm{F}=9.584, \mathrm{p}<0.001)$ with a $\mathrm{R} 2=0.130$.

\section{Regression Analysis of Obesity Related Factors in Patients without Concurrent Psychiatric Disorders}

Obese patients without any psychiatric co-morbidity $(n=112)$ were analyzed with regression analysis. The "backward" elimination method was performed with the accuracy rate of $72.3 \%$. Gender, years of education, level of income, Hamilton depression score and attachment style were determined to be unassociated and excluded. Age, living environment and Hamilton anxiety score were included and found to be associated with obesity in patients without concurrent psychiatric

Table 5. Linear regression analysis of factors related to BMI

\begin{tabular}{lcc}
\hline $\begin{array}{l}\text { Factors Related } \\
\text { to BMI* }\end{array}$ & $\begin{array}{c}\text { Standardized } \\
\text { â value }\end{array}$ & $\mathbf{p}$ \\
\hline Constant & & $<0.001$ \\
\hline Age & 0.146 & 0.048 \\
\hline Level of income & -0.155 & 0.035 \\
\hline $\begin{array}{l}\text { Hamilton anxiety } \\
\text { score }\end{array}$ & 0.276 & $<0.001$ \\
\hline *BMI: Body mass index & & \\
\hline
\end{tabular}

Table 4. Regression Analysis of Risk Factors Related to Obesity

\begin{tabular}{lcccc}
\hline & p & $\begin{array}{l}\text { Odds } \\
\text { Ratio }\end{array}$ & & \multicolumn{2}{c}{$\begin{array}{c}\text { \%95 Confidence } \\
\text { Interval }\end{array}$} \\
\cline { 4 - 5 } & & 1.072 & 1.033 & 1.112 \\
Hamilton & $<0.001$ & & & \\
\hline anxiety score & & & & \\
\hline Constant & 0.915 & 0.966 & & \\
\hline
\end{tabular}

disorder(Table 6).

\section{DISCUSSION}

We aimed to determine the psychiatric co-morbidity and attachment styles in obese patients. The results showed that psychiatric co-morbidity and insecure attachment styles were prevalent.

$40.3 \%$ of obese patients in our study did not indicate any psychiatric co-morbidity. The most prevalent psychiatric disorder was depression (33.8\%) (Table 3).

The relationship between depression and obesity has been well documented in many researches. The association of mood disorders with the propensity to become obese might be a consequence of side effects of antidepressants; subjective fatigue often described by patients with depression that results in diminished calorie expenditure; environmental and psychological factors like social isolation, underemployment, low self-esteem that lead patients to selfmedicate with large quantities of calori-rich foods (19). Otherwise, it is stated that the dysfunctions in the hypothalamopituitary system observed in some obese and depressed individuals are the biological evidence of the causal relationship $(20,21)$. On the other hand, studies showing a reduction of depressive symptoms following surgically induced weight loss in obese patients provide some data of reversibility of the effect of obesity. Moreover, there is some evidence of a dose-response effect of obesity severity on risk of depression (20). Researches examining the relationship between obesity and depression have largely consisted of large-scale, population based epidemiological studies (20). The highest 12-month prevalence rates of comorbid depression and obesity in individuals seeking bariatric surgery reported rates of preva- 
Table 6: Regression analysis of obesity related factors in patients without co morbid psychiatric disorders

\begin{tabular}{|c|c|c|c|c|}
\hline & \multirow[b]{2}{*}{ p } & \multirow[b]{2}{*}{ Odds Ratio } & \multicolumn{2}{|c|}{$\% 95$ Confidence Interval } \\
\hline & & & Lower limit & Upper limit \\
\hline$\overline{\text { Age }}$ & 0.034 & 1.037 & 1.003 & 1.073 \\
\hline Living environment * & 0.021 & & & \\
\hline Living environment $(1)^{* *}$ & 0.029 & 0.174 & 0.036 & 0.833 \\
\hline Living environment (2)*** & 0.265 & 1.889 & 0.617 & 5.777 \\
\hline Hamilton anxiety score & 0.001 & 1.098 & 1.037 & 1.163 \\
\hline Constant & 0.016 & 0.170 & & \\
\hline
\end{tabular}

lence ranging between 19-66\% (5). This wide range in prevalence rates can be attributed to the differences of methodology of the studies. In this study the prevalance rate of depression was $33.8 \%$. Although the prevalance rate coincided with rates found in the literature, there were slight differences (21). This may be due to the sample in this study consisting of mild and moderately obese patients rather than morbidly obese patients. We also investigated whether obesity was as a predictor of depression or if depression was a predictor of obesity. In a review, obesity was found to be prospectively associated with increased depression, or an onset of the disorder (22). However, we did not find depression as a predictive factor.

We also examined the relationship between attachment styles and psychiatric co-morbiditiy. 55.4\% of obese patients had insecure attachment styles. Insecure attachment styles were more in obese patients than the control group and also higher in obese patients with psychiatric co-morbidity.

Researches indicate that attachment styles can be conceptualized as a foundation of emotional regulation or one's ability to monitor, evaluate, and modify the magnitude/experience of emotion-eliciting events. Parental attachment is also associated with unhealthy eating patterns in children and adults (23). Emotion regulation failure is a core mechanism through which attachment and maladaptive eating behaviors are related (24).

We investigated whether attachment insecurity was one of the core risk factors for obesity and high BMI. We found that attachment insecurity, comorbid psychiatric disorder and depression scores were correlated with BMI and obesity. However, they were not found as risk factors for high BMI or obesity.
Anxiety was found as a risk factor of obesity and BMI in both patients with or without any psychiatric co-morbidity (Table 4). Anxiety was found to be an independent predictor of obesity and BMI (Table 5,6). In the literature the relationship between anxiety and obsesity has been well documented. Groezs and collegues (25) analyzed a large sample and found associations between stress exposure and increased drive to eat. Also, high levels of stress, anxiety and such other dysphoric mood states as anger and sadness might alter eating behaviors $(19,26)$. In a population based study of 2579 adults who were followed longitudinally over 9 years to assess psychosocial factors, it was observed that psychosocial stress was associated with greater weight gain (27). If we contextualize our data with the literature findings we can consider that the initial sign of stress is anxiety, which is why we determine anxiety to be a risk factor for obesity and high BMI. The symptom of anxiety might be a precursor of attachment insecurity or any psychiatric co-morbidity especially depression.

According to the findings of this study, attachment insecurity was not found as a risk factor for obesity. But in the literature there are contrary findings. In two studies, insecure attachment styles were found to be a risk factor for being obese. Cooper and Warren (28) investigated the relationship between attachment and obesity in a population of young women and evaluated the attachment styles with the attachment history questionnaire. They found that higher BMI was associated with more negative parental discipline. Additionally, they also indicated that anxiety and depressive symptoms are related with attachment styles and BMI. D'Argenio and colleagues (29) investigated whether exposure to early-life events was associated with increased risk of adult obesity. They analyzed the role of anxious attachment as a potential mediator between early 
trauma and adult obesity. Eventually, they found that anxious attachment was one of the predictors of adult obesity.

The literature shows that obesity, attachment styles and mental disorders have a substantial relationship (30). If we contextualize this data with the literature findings, the symptom of anxiety might be considered an initial sign of psyhiatric comorbidity or attachment insecurity, which was also found as a risk factor for obesity and high BMI.

\section{Limitations}

First, the cross-sectional nature of the data limits any speculation about causality. Obviously, longitudinal studies and repeated measurements will better clarify the relationship between obesity and risk factors associated with obesity. Second, the evalution of attachment styles was conducted with a self-report scale instead of the Adult Attachment Interview because the Turkish version of the Adult Attachment Interview was not validated.

Our control group contains a overweight and underweight individuals. The characteristics of overweight individuals, who may be regarded as a preliminary stage in terms of obesity and characteristics of underweight individuals are not well known and possible confounding effects on the results of their involvement in the control group should be considered.

Additionally, we have to emphasize that the findings of this study cannot be generalized to obese patients who seek different (surgical and nonsurgical) forms of treatment or to non-treatment-seeking community populations. The findings are preliminary and based on the population of a clinical sample of mild-moderate obese individuals.

\section{CONCLUSION}

Psychiatric co-morbidity and insecure attachment styles were found to be prevalent in obese patients. Depression was identified as the most prevalent psychiatric disorder. Attachment insecurity, comorbid psychiatric disorder and depression scores were related to high BMI and obesity. However, they were not found to be risk factors. Anxiety was found to be an independent predictor of obesity and higher BMI.

Finally, we suggest that obese patients either referring to bariatric surgery or to clinical settings should have psychiatric examinations. If it is not possible, making simple self report evalutions for attachment styles and anxiety symptoms will be adequate. This may help clinicians to identify the risk factors for obesity and high BMI. Awareness of the associations between attachment, depression, anxiety and obesity may enable proffessionals to perform attachment-anxiety based interventions in the treatment programs.

\section{Acknowledgement}

We thank Dr. Deniz Kutluay and Dr. Savaş Gür for their support to data collection stage.

Correspondence address: M.D. Ebru Aldemir, Ege University Institute on Drug Abuse, Toxicology and Pharmaceutical Science, İzmir, Turkey ozturk.ebru2000@gmail.com 


\section{REFERENCES}

1. Flegal KM, Kit BK, Orpana H, Graubard BI. Association of all-cause mortality with overweight and obesity using standard body mass index categories: a systematic review and meta-analysis. JAMA 2013;309:71-82.

2. Swencionis C, Rendell SL. The psychology of obesity. Abdom Imaging 2012;37:733-737.

3. van HoutGC, van Oudheusden I, van Heck GL. Psychological profile of the morbidly obese. Obes Surg 2004;14:579-588.

4. Martin-Rodriguez E, Guillen-Grima F, Martí A, BrugosLarumbe A. Comorbidity associated with obesity in a large population: The APNA study. Obes Res Clin Pract 2015;9:435-447.

5. Preiss K, Brennan L, Clarke D. Obesity Comorbidity A systematic review of variables associated with the relationship between obesity and depression. Obesity Reviews 2013;14:906918.

6. Koskina N, Giovazolias T. The effect of attachment insecurity in the development of eating disturbances across gender: The role of body dissatisfaction. Journal of Psychology: Interdisciplinary and Applied 2010;144:449-471.

7. Levy KN, Ellison WD, Scott LN, Bernecker SL. Attachment style. J Clin Psychol 2011;67:193-203.

8. Hunter JJ, Maunder RG. Using attachment theory to understand illness behavior. Gen Hosp Psychiatry 2001;23:177-182.

9. van Vlierberghe L, Braet C, Goossens L. Dysfunctional schemas and eating pathology in overweight youth: a case-control study. Int J Eat Disord 2009;42: 437-442.

10. Tasca GA, Balfour L. Attachment and eating disorders: A review of current research. Int J Eat Disord 2014;47: 710-717.

11. Illing V, Tasca GA, Balfour L, Bisssada H. Attachment insecurity predicts eating disorder symptoms and treatment outcomes in a clinical sample of women. J Nerv Ment Dis 2010; 198: 653-659.

12. Troisi A, Massaroni P, Cuzzolaro M. Early separation anxiety and adult attachment style in women with eating disorders. Br J Clin Psychol 2005; 44(Pt 1): 89-97.

13. First MB, Spitzer RL, Gibbon M, Gibbon W, Janet BW. Structured Clinical Interview for DSM-IV Axis-I Disorders Clinical Version (SCID-I/CV). Washington DC: American Psychiatric Press; 1996

14. Akdemir A, Türkçapar MH, Orsel SD, Demirergi N, Dag I, Ozbay MH. Reliability and validity of the Turkish version of the Hamilton Depression Rating Scale. Compr Psychiatry 2001; 42:161-165.

15. Yazııı MK, Demir B, Tanrıverdi N, Karaağaoğlu E, Yolaç P. Hamilton Anxiety Rating Scale interrater reliability and validity study. Turkish Journal of Psychiatry 1998; 9:114-117.

16. Hazan C, Shaver P. Romantic love conceptualized as an attachment process. Journal of Personality and Social Psychology 1987;52:511-524.

17. Mikulincer M, Florian V, Weller A. Attachment styles, coping strategies, and posttraumatic psychological distress: the impact of the Gulf War in Israel. Journal of Personality and Social Psychology 1993; 64:817-826.
18. Kesebir S, Kökçü F, Dereboy F. Adult Attachment Style Scale: Adaptation, Reliability and Validity Study. New Symposium 2012; 50: 99-104.

19. Wurtman J, Wurtman R. The Trajectory from Mood to Obesity. Curr Obes Rep. 2018;7:1-5.

20. Atlantis E, Baker M. Obesity effects on depression: systematic review of epidemiological studies. Int $\mathbf{J}$ Obes (Lond). 2008;32:881-891.

21. Stunkard AJ, Faith MS, Allison KC. Depression and obesity. Biol Psychiatry 2003;54:330-337.

22. Faith MS, Butryn M, Wadden TA, Fabricatore A, Nguyen AM, Heymsfield SB. Evidence for prospective associations among depression and obesity in population-based studies. Obes Rev 2011; 12: 438-453.

23. Faber A, Dubé L. Parental attachment insecurity predicts child and adult high-caloric food consumption. J Health Psychol 2015;20:511-524.

24. Goossens L, Braet C, Van Durme K, Decaluwe V, Bosmans G. The parent-child relationship as predictor of eating pathology and weight gain in preadolescents. J Clin Child Adolesc Psychol 2012;41:445-457.

25. Groesz LM, McCoy S, Carl J, Saslow L, Stewart J, Adler N, Laraira B, Epel E. What is eating you? Stress and the drive to eat. Appetite 2011;58:717-721.

26. Sinha R, Jastreboff AM. Stress as a common risk factor for obesity and addiction. Biol Psychiatry 2013;73:827-835.

27. Block JP, He Y, Zaslavsky AM, Ding L, Ayanian JZ. Psychosocial stress and change in weight among US adults. Am J Epidemiol 2009;170:181-192.

28. Cooper MJ, Warren L. The relationship between body weight (body mass index) and attachment history in young women. Eating Behaviours 2011;12:94-96.

29. D'Argenio A, Mazzi C, Pecchioli L, Di Lorenzo G, Siracusano A, Troisi A. Early trauma and adult obesity: is psychological dysfunction the mediating mechanism? Physiology Behaviour 2009;98:543-546.

30. Malik S, Mitchell JE, Engel S, Crosby R, Wonderlich S. Psychopathology in bariatric surgery candidates: a review of studies using structured diagnostic interviews. Compr Psychiatry 2013;55:248-259. 